\title{
Innovations in Online Advertising Management of Ukrainian Business Entities
}

\author{
Aleksandr Teletov ${ }^{1}$, Svetlana Teletova $^{2}$, Nataliia Letunovska ${ }^{3}$, Valeriia Lazorenko ${ }^{4}$ \\ ${ }^{1}$ Doctor of Economic Sciences, Professor, Professor of the Department of Marketing, Sumy State University, \\ Ukraine, \\ ${ }^{2} \mathrm{PhD}$ in Philological Sciences, Associate Professor, Associate Professor of the Department of Russian and World \\ Literature, Sumy State Pedagogical University named after Makarenko, Ukraine \\ ${ }^{3} \mathrm{PhD}$ in Economic Sciences, Senior Lecturer of the Department of Marketing, Sumy State University, Ukraine, \\ n.letunovska@gmail.com \\ ${ }^{4}$ Student of the Oleg Balatskyi Academic and Research Institute of Finance, Economics and Management, Sumy \\ State University, Ukraine
}

\begin{abstract}
The purpose of this article is to substantiate theoretical provisions and develop recommendations for innovative advertising management of enterprises producing biological preparations. The study analyzes the features of the modern Ukrainian market of veterinary products, in particular in the segment of biological products. The authors focus on innovative advertising tools in the industrial sphere. The authors substantiate the importance of the image of biological products producers. The analysis of websites and targeted advertising features in Facebook social network for the producers of this profile are made.
\end{abstract}

Key words: innovations in online advertising management, Internet marketing, social network, targeted advertising, site of a business entity, traffic, targeted audience.

\section{INTRODUCTION}

\subsection{An industrial manufacturer of biologicals as an object of analysis}

The current market of veterinary drugs of Ukraine is constantly expanding in terms of quantity and quality. In recent years, it has become very attractive for business. Increasing the number of companies and the production of veterinary products increases market competition and encourages manufacturers to seek and use new strategies to enhance their image, gain consumers and retain market share. The market for veterinary products is divided into 6 main areas: chemical, biological, feed, disinfectants, other veterinary preparations products. The largest distribution of the veterinary market is in biological industries (vaccines, medical sera, diagnosticum products, nutrient mediums).
We have chosen Ukrainian producers of biological products as an object for analysis. We propose to consider Internet marketing to improve the efficiency of their activities.

The specificity of bioproducts is that not all vaccines are single use. Many vaccines are used throughout the life of an individual animal (revaccinations). Demand for products is seasonal. Most sales are in the spring when there is a need for additional immunity.

Vaccine buyers are veterinary laboratories, veterinary pharmacies, circus companies, zoos, farms, poultry farms, pig farms, cattle breeds, slaughterhouses, animal sport organizers and pet owners.

The share of biological products in the value structure of the domestic market by pharmacotherapeutic groups is about $34.6 \%$ (vaccines for poultry, rabbits, pigs, cattle, bees, etc., test systems). In addition, under the influence of new lifestyles, the proportion of the pet segment (11-13.4\%) is increasing every year [1]. When segmenting the market of biological products in Ukraine, it is reasonable to say that this market is characterized by the lack of latest preparations developments which is connected with limited economic opportunities of Ukrainian manufacturers and buyers of preparations. Major segments of the market: self-developed products (new preparations having analogs [2]; new preparations for the domestic market, made in cooperation with foreign companies; new generic preparations under their own brand names for the domestic market. Generics are analogues of the original preparations that begin to be manufactured by other manufacturers after the patent protection of the original product has expired [3].

1.2. Innovative instruments of communication for business entities: the role of Internet marketing in the market activity of a manufacturer of biological products

In the context of farm-oriented trends, there is a need for primary processing of meat and milk directly near farms that 
can replace multi-ton refrigeration tanks. So, the need for high-quality biological veterinary products is increasing for many agricultural professionals. The accessibility and ease of their acquisition should be supported by effective advertising management. The relevance of innovative methods of biological products promoting is that only few enterprises of this profile have effective online representation. Online activity shows how powerful is a company today. Modern instruments of advertisiment are not used in the vast majority of enterprises in bioproducts manufacturing field.

The purpose of the study is to substantiate theoretical provisions and develop recommendations for innovative advertising management of enterprises producing biological veterinary preparations.

According to statistics, almost $80 \%$ of buyers start the process of buying by monitoring information online. The role of service as an element of competition, which is judged by the quality of communications is in the B2B and B2C markets (mainly used by manufacturers of biological products).

Not many scientific works have been devoted to the problems of Internet marketing in biological products industry [4-12]. Some information on this issue is being considered in professional print and online publications in Ukraine and abroad.

According to the research, both industry executives and Internet marketing professionals are uniquely calling the site a major and integrated marketing tool [13].

Own website gives industrial companies unique opportunities for globalization and transition from "mass" marketing to customized marketing. The site is better than other tools provides qualitive information, supplementing it with interesting illustrative content. In addition to 24/7 accessibility, another advantage of site is the ability to integrate all elements of marketing mix). In this regard, we argue that the online marketing of bioproducts must always start with the site. It is appropriate to focus a large portion of your financial and time resources on it. The promotion of a corporate site should be supported by social networks. Interactive communication with consumers is facilitated by the existing registration process on a site, conducting surveys among clients, organizing e-mail newsletters, implementing loyalty programs, etc.

Site allows to solve such issues:

- negative demand for biological products when a significant proportion of potential consumers refuse a specific type of product (due to lack of sufficient information). Site is the instrument of conversion marketing in this case;

- low demand when serving as an incentive marketing tool site distributes necessary information about biological preparations increasing interest in buying among potential consumers.

\section{RESULTS AND DISCUSSION}

The leading domestic manufacturer of veterinary preparations in Ukraine is the O.L.KAR.-AgroZooVet-Service enterprise, which produces more than 1,000 items of various veterinary products. Other Ukrainian manufacturers are presented in Table. 1.

In addition to Ukrainian manufacturers, more than 70 foreign companies (Bayer (Germany), INVESA (Spain), Biowet Pulawy (Poland), PFIZER (USA), Armavir Biofabrika (Russia), Huevepharma (Bulgaria), Syva Laboratorios S.A. (Spain) occupy almost $95 \%$ of the foreign veterinary preparations market in Ukraine) from 40 countries are represented in the market. Products of manufacturers from Belarus, the Netherlands, China, South Korea, Slovenia are also presented. According to the results of the third quarter of 2019 , domestic products occupied $54 \%$ of the market [14]. The rest of the market is foreign production. Most buyers trust domestic products because the vaccine is already time-tested. Foreign companies are often less aware of the needs of the Ukrainian market for vaccines of a particular kind and purpose.

Table 1: Product Range of Leading Veterinary Preparations Manufacturers in Ukraine

\begin{tabular}{|c|c|}
\hline Manufacturer & $\begin{array}{c}\text { Number of veterinary } \\
\text { preparations (units of } \\
\text { names) }\end{array}$ \\
\hline $\begin{array}{c}\text { PJSC PSE } \\
\text { "Ukrzovetprompostach" }\end{array}$ & 170 \\
\hline LLC PF "Bazalt" & 160 \\
\hline LLC "Brovafarma" & 130 \\
\hline PE "Farmaton" & 125 \\
\hline LLC "Vetsyntez" & 111 \\
\hline LLC "BioTestLab" & 99 \\
\hline SE «Sumy Biological Factory» & 80 \\
\hline LLC "Product" & 66 \\
\hline LLC "Urkvetprompostach" & 65 \\
\hline JSC "Biofarm" & 49 \\
\hline SE "Kherson Biological Factory" & 21 \\
\hline
\end{tabular}

The image of the company plays an important role in the veterinary preparations market, which is characteristic for many industrial markets. This is confirmed by the results of the studies. Consumers pay attention to external factors formulated by a company before making a purchase. These include the opinions of customers who have already used a product, the opinion of industry experts. The main mission of promoting and maintaining the image of bioproduct manufacturers is to preserve and increase livestock production in Ukraine. The main components of the image for veterinary businesses are vaccine effectiveness, sales department, response to customer's queries, system of product delivery and corporate style. Production department of an enterprise is responsible for the vaccine's effectiveness. The first contact of 
a client with company occurs with sales consultants. Biological products are complex, so the sales team always accompanies consumer. To create an external image of a veterinary preparations manufacturer in today's changing environment with a focus on Internet communications, the presence of a company's website and the effectiveness of its work play important role [15].

Unlike in European countries, the Law of Ukraine "On Advertising" [16] has no restrictions on the marketing of veterinary products.

Advertising of veterinary preparations, in particular biological products, is considered by us in the following directions:

- Industrial advertising. Brochures, advertising materials in professional journals, technical literature and catalogs, industry exhibitions, technical demonstrations and seminars. The largest industry exhibitions in Ukraine are Agroforum (exhibition of innovative products for agriculture), Agro2019 (the largest agricultural exhibition in the country), Agrocomplex (exhibition of effective solutions for agrarian industry), International Dairy Congress (veterinary dairy production exhibition), Agro Animal Show (international exhibition of effective livestock and poultry) and others. The most well-known professional thematic journals are "Animal husbandry and veterinary medicine", "World of veterinary science", "Veterinary medicine, animal husbandry and nature management technologies". A number of universities hold annual seminars on veterinary research in Ukraine (Sumy National Agrarian University, Zhytomyr National Agro-Ecology University, National University of Bioresources and Environmental Management of Ukraine, etc.).

- Retail advertising. For veterinary medicine companies it is a question of veterinary pharmacies. The objective of such advertising is to attract the attention of potential consumer to manufacturer and increase the sales of goods of a particular enterprise at the selected point of retail (press advertising, namely specialized newspapers and industry journals, on-site advertising, outdoor advertising, transportation advertising and online advertising.

- Contact advertising. It is used for direct sale. The sale can be made by phone order or online. During the ordering process, the enterprise manager offers additional goods or services to increase the sales volume of goods. The audience for agricultural advertising is composed of farmers and other agricultural workers, who are both consumers and entrepreneurs.

All tools of advertising have advantages and disadvantages. Nowadays, the use of the Internet advertising becomes especially relevant. One of modern types of advertising on the Internet is targeted advertising. It is a channel of promotion on social networks, aimed at a specific target audience with well-defined parameters.

So, we have highlighted the main types of advertising that are used in marketing activities of modern veterinary products manufacturers in Ukraine. Consider the example of domestic producers of biological veterinary preparations in promoting their products on the market using Internet marketing

\section{EXPERIMENTAL}

We have found out that the main factor for evaluating a business in the modern world is its presentation on the Internet. There may be sites with a wide product range for large enterprises, for the small ones with narrow product range land or social networks are advisable. With regard to the veterinary field, lands are used mainly for intermediaries in the production of biological factories, i.e. veterinary pharmacies or hospitals.

Veterinary businesses have complex products, so it is more appropriate to choose a site for online business. All information on site should be structured and understandable to potential customers. Most of those who know the effect of the products are veterinarians, but site needs to be designed so that individuals without special education could understand what the issue is about.

We compare the sites of the main competitors in biological vaccine production in Ukraine: SE "Sumy Biological Factory", SE "Kherson Biological Factory" and LLC "BioTestLab" (Kyiv). Consider the basic criteria for competitive site analysis:

1. Usability.

2. Site structure.

3. Site indexing.

4. Number of external pages.

5. Total traffic.

6. Behavioral factors: refusals, page depth, time spent on site.

7. Traffic sources: direct, referrals, SEO, SMM, Email Marketing and banner advertising.

8. Adaptability to the mobile version.

Usability criteria for veterinary business websites are color gamma, font, image placement, site load speed and identity. Usability for biological product manufacturers is the primary indicator of keeping comparability between colors of a site and corporate style. SE "Sumy Biological Factory" uses a pastel-blue color scheme. Pictures posted on the site are long-loaded, but all of good quality. There are different fonts which are difficult to perceive. SE "Kherson Biological Factory" has landing page that is very simplistic. The color scheme is unattractive. Too much green is present. Pictures are different in form and format. Almost $50 \%$ of photos are downloaded from the Internet. The fonts on the site are different. The site of LLC "BioTestLab" differs from competitors. It is the most organized. There is a fast and continuous playback video screensaver on the homepage. The site is made in the same style. There is a variety of colors, but for the most part site is presented in a light green.

The structure of site shows how convenient the main tabs on site are, how easy it is to find the information you need. It should be ergonomic. Website of SE "Sumy Biological Factory" has easy structure. It which consists of the following tabs: "About the company", "Product catalog", "Cooperation", "Contract production", "Prices" and "Contacts". The structure 
of the site of SE "Kherson Biological Factory" includes such tabs: "Main", "Products", "About us", "Contacts". The structure is concise. There is not enough information to make a decision. There is no price tab. The main page contains news dating back to 2017. If the company was presented as a landing, then it was necessary to provide the following basic information to potential customers: "Information about product and its application", "Prices", "Company" and "Contacts". Site of LLC "BioTestLab" has the following structure: "Company", "Infocenter", "Production", "Products" and "Contacts". It is concise and understandable. The price tab is missing. New information about products is presented in the tab "Infocenter".

Site indexing reflects the number of pages in the search engine. Google was chosen as the main search engine for the study. The more pages, the more traffic we can get to a page on the Internet.

External links are all sources that link to a specific site. In other words, they are called donors. The main donors may be suppliers of raw materials, resellers, potential customers and clients. The more companies we can engage with online, the more potential customers will go to a particular site. You can interact and be a barter donor.

Total traffic shows the number of visitors to specific site over a given selected period. One user can visit the site several times, so the total traffic does not match the actual number of people who visited it. Consider the listed characteristics for competing sites in Table 2.

Table 2: Comparison of the Sites of Biological Products Manufacturers by Page Count, External Links and

Total Traffic

\begin{tabular}{|c|c|c|c|c|}
\hline 昰 & 䓵 & 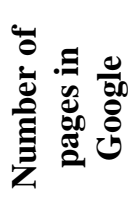 & 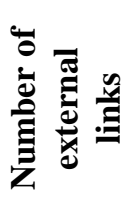 & 苞 \\
\hline $\begin{array}{l}\text { SE "Sumy } \\
\text { Biological } \\
\text { Factory" }\end{array}$ & $\frac{\underline{\text { http://biofa }}}{\text { brika.sumy }}$ & 155 & $\underline{24}$ & 172 \\
\hline $\begin{array}{l}\text { SE "Khers } \\
\text { on } \\
\text { Biological } \\
\text { Factory" }\end{array}$ & $\frac{\frac{\mathrm{http}: / / \mathrm{kher}}{\text { sonbiofabri }}}{\text { ka.com/ }}$ & 59 & $\underline{5}$ & 420 \\
\hline $\begin{array}{l}\text { LLC "Bio } \\
\text { TestLab" }\end{array}$ & $\frac{\frac{\text { https://ww }}{\text { w.biotestla }}}{\text { b.ua/ }}$ & 692 & $\underline{26}$ & 11,540 \\
\hline
\end{tabular}

The leader by the number of pages and total traffic is LLC "BioTestLab". A large amount of traffic depends on factors such as the city where the enterprise is located (the capital of Ukraine), the number of registered farms nearby, the effectiveness of sales managers, etc.

There are three parameters to characterize behavioral factors: refusals, page depth and time spent on the site (Table 3). A site refusal occurs when a user $\operatorname{logs}$ in to a site and visits only homepage without taking any action, that is, a click. Page depth displays the number of pages a user navigates.

Table 3: Comparison of Visitor Behavior on Competitors' Sites

\begin{tabular}{|c|c|c|c|}
\hline \multirow{2}{*}{ Enterprise } & \multicolumn{3}{|c|}{ Behavior factors } \\
\cline { 2 - 4 } & Refusals & Depth & Time \\
\hline $\begin{array}{c}\text { SE "Sumy } \\
\text { Biological Factory" }\end{array}$ & $68 \%$ & 3.1 & $34 "$ \\
\hline $\begin{array}{c}\text { SE "Kherson } \\
\text { Biological Factory" }\end{array}$ & $66 \%$ & 2.5 & $32 "$ \\
\hline LLC "BioTestLab" & $59 \%$ & 1.88 & $2^{\prime} 06^{\prime \prime}$ \\
\hline
\end{tabular}

The users' refusals on the sites of surveyed enterprises are quite positive for the veterinary field as they do not have a direct "Buy" or "Order" buttons. The depth of site is the best in SE "Sumy Biological Factory," which can be explained by the fact that the necessary information for consumer is many steps, or the consumer is interested in learning more about the factory. The best behavioral factor that shows how much a site is liked by a potential customer is their time spent. The most competitive by this parameter is LLC "BioTestLab". Such statistics is caused by the interest of international counterparties who have visited the site and spent a long time on it. Not a deep site can indicate that all the necessary information is located in the least number of steps.

Consider all traffic sources for surveyed companies in Table. 4.

Table 4: Sources of Traffic to Competing Sites

\begin{tabular}{|c|c|c|c|c|c|c|}
\hline \multirow[b]{2}{*}{ 总 } & \multicolumn{6}{|c|}{ Sources of traffic, \% } \\
\hline & 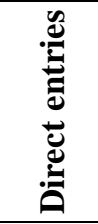 & 包 & $\begin{array}{l}\text { 잉 } \\
\text { 我 }\end{array}$ & $\sum_{\infty}$ & 苞 & 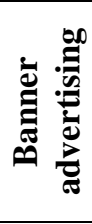 \\
\hline 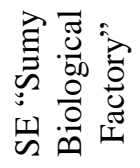 & 37.94 & 0 & 56.11 & 5.96 & 0 & 0 \\
\hline 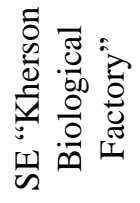 & 0 & 25.85 & 48.3 & 25.85 & 0 & 0 \\
\hline 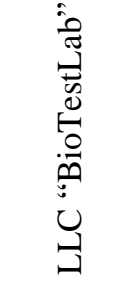 & 14.72 & 0.22 & 84.36 & 0.7 & 2 & 0 \\
\hline
\end{tabular}


The Sumy and Kherson factories use only half of the capabilities of a website's promotion tools to attract traffic. Direct actions can be an indicator of how loyal customers are to a particular business. All analyzed sites have optimization that helps users to find them quickly.

With regard to SMM, the best efficiency is observed in SE "Kherson Biological Factory". Most often, the referrals are from social networking sites and resellers who post factory information in their social accounts. The close relationship is shown in the referral statistics. This shows the good relationships the factory has with its employees, resellers, suppliers and customers. SE "Sumy Biological Factory" has no representation on social networks, although it has a high percentage of traffic sources. This situation can be triggered by discussions of targeted product customers on various social media pages.

The simplest of the elements of traffic sources is email marketing. It is aimed at legal entities present in the veterinary field. Email addresses of farms and veterinary pharmacies are not difficult to find and send out with a sales offer. Different messages should be made for each target buyer, depending on the species and the number of animals in the holding. Under the conditions of administrative reform and creation of integrated territorial communities in rural areas (it is estimated that at the completion of the reforms in Ukraine there will be about two thousand communities [17]. Ukrainian farmers should actively develop. Today, there are more than 26 thousand farms in Ukraine, which is less than $10 \%$ of their possible number. The most efficient farming is focused on livestock products, the production and export of which is more stable in line with crop production. The dairy cluster and the pig-breeding cluster are powerful here, and the lamb cluster is also promising.

Effective use of the Internet to promote products is in LLC "BioTestLab", which uses the maximum number of indicators. This company uses direct actions, referrals, SEO, SMM and email marketing.

Developed sites generally contain all six traffic source metrics in their activity. Modern trend is that the use of smartphones to access the Internet is gaining in popularity. Mobile phones account for almost half of the time people spend on the Internet. It is important for site of a biological products manufacturer to be customized for the mobile version.

Veterinary business can be targeted on social networks for sale, but this is the next step after creating a friendly atmosphere between seller and buyer. Social networks have different target audiences. To orient business in the social space, you should first determine the target audience that will be most successful in promoting your product. Currently in Ukraine there are such popular social networks: Facebook (used by about $44 \%$ of respondents), Instagram (used by $18 \%$ of respondents), Twitter (used by 5\% of respondents). Other social networks account for 33\% of respondents' answers [18].
Facebook is the main social network for the biological factories promotion, as the target audience is over 25 years old. This audience already has education and can independently decide on the purchase of such a complex product.

The stage of creating a page on a social network goes through the following stages: gathering information, choosing the way of bringing information (creating a page, group or account), creating a page / account / group under a company name, adding relevant information and contacts, creating and filling a page with content, inviting potential customers. We compare the advantages and disadvantages of account, group and page (Table 5). For industrial enterprises, it's better to create a social networking page because it has the best functionality for doing business.

The quality of images on a page requires certain parameters. Different types of photos fit into different geometric shapes, which is why you need to follow the rules of extension. For example, the main photo of a page fits in a circle. The cover fits in a rectangle. In order to provide better image quality to profile pictures, you should save them in PNG format. You can use the following resources to create the content yourself: https://www.canva.com and https://crello.com. These resources include free templates, but also available paid content. Some ideas for a veterinary business can be found in such tabs as "Animals" and "Medicine".

Table 5: The Difference between Presenting Enterprises on Facebook Social Network

\begin{tabular}{|c|c|c|}
\hline $\begin{array}{c}\text { Way of } \\
\text { bringing } \\
\text { informa } \\
\text { tion }\end{array}$ & Advantages & Disadvantages \\
\hline Account & $\begin{array}{l}\text { 1The ability to invite an } \\
\text { audience in one step. } \\
\text { 2. Easy of use. } \\
\text { 3. New posts cover all } \\
\text { friends. } \\
\text { 4. Visibility in news } \\
\text { feed. }\end{array}$ & $\begin{array}{l}\text { 1. Lack of statistics } \\
\text { control. } \\
\text { 2. Only } 5,000 \text { people } \\
\text { can be added to } \\
\text { friends. } \\
\text { 3. Administration } \\
\text { may not allow an } \\
\text { account with a } \\
\text { suspicious name. } \\
\text { 4. Advertising and } \\
\text { sales are blocked by } \\
\text { the administration. }\end{array}$ \\
\hline Group & $\begin{array}{l}\text { 1. Group posts are } \\
\text { visible in the group } \\
\text { members' news feed. } \\
\text { 2. Personal messaging } \\
\text { (up to 5,000) is } \\
\text { possible. } \\
\text { 3. The ability to make a } \\
\text { group "closed" (for } \\
\text { VIP-clients only). }\end{array}$ & $\begin{array}{l}\text { 1. Two steps are } \\
\text { required to invite a } \\
\text { potential audience } \\
\text { (Add to friends - } \\
\text { Invite to group). } \\
\text { 2. Groups cannot be } \\
\text { advertised. } \\
\text { 3. Visible only to that } \\
\text { users who are invited } \\
\text { or intentionally }\end{array}$ \\
\hline
\end{tabular}


Aleksandr Teletov et al., International Journal of Advanced Trends in Computer Science and Engineering, 9(1.2), 2020, 272 - 279

\begin{tabular}{|c|c|c|}
\hline $\begin{array}{c}\text { Way of } \\
\text { bringing } \\
\text { informa } \\
\text { tion }\end{array}$ & Advantages & Disadvantages \\
\hline & & searches for a group. \\
\hline Page & $\begin{array}{l}\text { 1. Ability to create an } \\
\text { event and invite the } \\
\text { target audience. } \\
\text { 2. More functionality } \\
\text { for visitors. } \\
\text { 3. Ability to promote } \\
\text { the page (targeting). } \\
\text { 4. Statistics available. } \\
\text { 5. Unlimited audience. } \\
\text { 6. Option to set the } \\
\text { mode "not online" }\end{array}$ & $\begin{array}{l}\text { 1. Two steps are } \\
\text { required to invite } \\
\text { potential audiences } \\
\text { (Add to friends - } \\
\text { Invite to page). } \\
\text { 2. Complex interface } \\
\text { for use }\end{array}$ \\
\hline
\end{tabular}

One of the key tools on a page in social network is survey. It helps to focus issue under consideration. It seems that client's opinion is important and influences the voting. For veterinary businesses, the following survey topics are possible: about farm animals, about pets, about vaccination and revaccination, about the weight of animals and others.

Searching for clients of veterinary businesses is not complicated. Engaging consumers on a Facebook social network page is possible by searching for similar groups or livestock accounts where a target audience is located. There are many veterinary referral pages on Facebook. A company can join other pages and groups and post on its own behalf. The benefits of this search:

- publications are related to topics;

- consumers are interested in such information;

- page administration does not need to make additional posts a day to keep audience engaged.

Practical application of targeting advertising. All Facebook advertising is done through Ads Manager. It lets view, edit and track all created advertising campaigns, groups and individual ads on Facebook. First you need to determine the purpose of creating a Facebook advertising campaign. Topics for advertising a biological products business page can be: directing people to a website, increasing conversions on a site, promoting posts and page promoting. The main categories of choice for advertising campaigns for veterinary preparations manufacturers are: awareness (brand awareness and audience reach) and views (traffic and audience engagement).

Depending on the purpose, you need to choose where your potential audience will go: site views or messenger (Figure 1). A more effective parameter for optimizing your ad campaign is "Clicks on the tab". Parameter "Shows" is less effective but has a larger audience. Optimization for displaying manufacturers' ads is better targeted at "Clicks on the link".

Budgeting and evaluating the performance of targeting ads. You can install or not install deadline for ads. In this case, the advertisement will be valid until the moment of lack of funds in the account (Figure 2). It is important to choose the duration of advertisement, either daytime or full time.

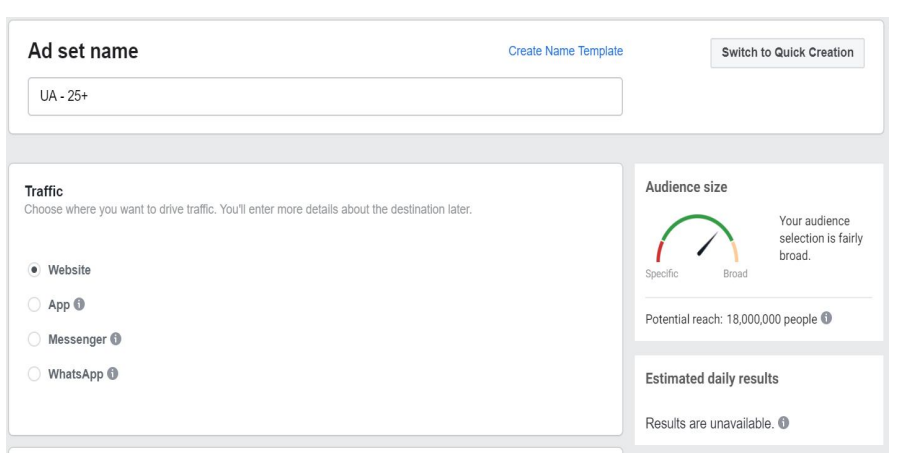

Figure 1: Choosing a Traffic Destination

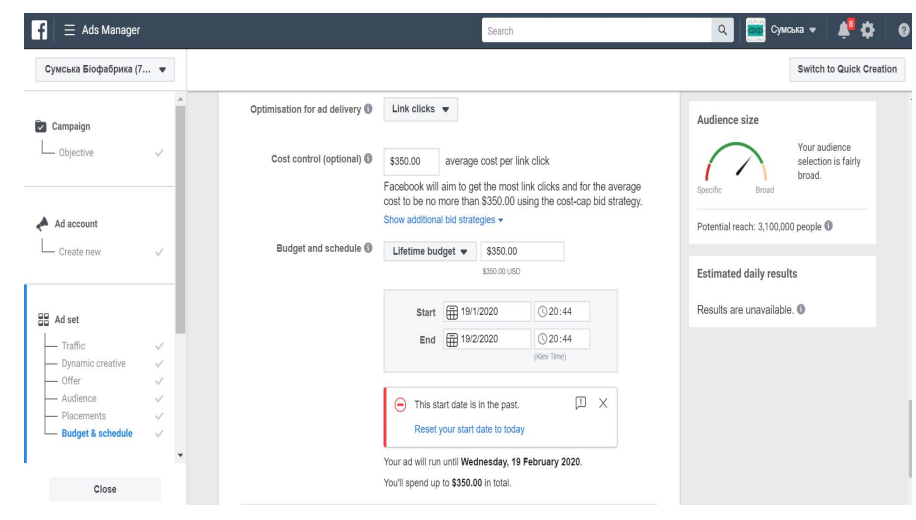

Figure 2: Targeted Advertising Budget

For such parameter as "Location" we choose the whole Ukraine, or choose a segment that we would like to enter into. If a business fully covers a particular locality, it may exclude it from the list. Delivery of the vaccine of studied enterprises can be made to any corner of Ukraine. Therefore, it is not appropriate to use the location tool. The best age to target ad campaign of biological products manufacturer is 30 years. When choosing a gender, we select the parameter "All", since both men and women can be buyers of products. Interests that are most relevant to the target audience: farm animals, animal welfare, farming, rabbits and more.

Communication is a special and important component. Depending on the subject matter of the advertising campaign, it can be distributed to people who have liked a company page, friends of people who have liked business page, all except for subscribers. The last one is targeted when the purpose of advertising campaign is to raise the awareness of a potential group of people about manufacturer.

Next is creating advertising. The ad format is selected (image or video). It is difficult for vaccine companies to develop informative videos and attract viewing, so it is best to use a product picture. It is important to place company logo on the image for better identification among competitors. Next, we upload the image and stick to its format. We add main text, 
title and description of advertisement. We check text and add the URL of a site. The call-to-action for animal vaccine manufacturers can be: if product advertising is "Contact us", "Get a unique offer", if traffic attraction is "Subscribe" and "Learn more". Then we click "Review and publish". After that advertising campaing starts. Further, you need to monitor performance and analyze statistics.

The considered steps are unified to create an advertising campaign for any industrial enterprise in Ukraine. Targeted advertising opens up new opportunities for the Ukrainian biological preparations market. It focuses more on individuals and helps attract new target audiences to collaborate with business. Such advertising is costly but has a positive economic impact.

\section{CONCLUSION}

The study concludes that a significant effect of the online promotion of an industrial enterprise, in particular in the field of veterinary preparations, can be expected in the case of combined use of site and a set of additional tools for its promotion, for example, the SMM promotion method.

In the context of the administrative reform of Ukraine in the countryside, communication support will create a positive perception of manufacturers of biological products, which will facilitate the impact of advertising management on the subjects of small and medium-sized agricultural businesses. A feature of veterinary products advertising is that it is aimed at reporting the existence of specific brands of goods for agricultural producers; ensuring the acceptance of advertised products by dealers; forming a better attitude of farmers to a particular veterinary product by demonstrating how those products help to increase efficiency, reduce business risk, increase profit margins and more. The authors substantiate that the main components of the image for veterinary businesses are vaccine efficacy, reliability of sales service, prompt response, timely delivery and corporate style. The image accompanies manufacturing company throughout the process of production and sale of biological products. The factors considered are common to most veterinary businesses. Almost every company has its own competitive environment, relevant sites, etc., so the strategy of promoting business on the Internet involves regular analysis of them. The main comparative indicators of competitive analysis of sites are determined. According to the authors' analysis, all Ukrainian producers of biological preparations for animals are presented on the Internet.

Innovations in the advertising management of biological preparations include targeted online advertising. The stages of targeting advertising on the Facebook network are unified for the advertising campaign of any veterinary enterprise in Ukraine. The authors conclude that targeted advertising opens up new opportunities for the Ukrainian biological preparations market, because it is more targeted at individuals who are not available to manufacturers and helps to find and engage a target audience in cooperation with an enterprise.

\section{ACKNOWLEGEMENT}

The authors would like to thank Oleg Balatskyi Academic and Research Institute of Finance, Economics and Management of Sumy State University and particurly the Department of Marketing for their support. The authors would like to acknowledge the Sumy State Pedagogical University named after Makarenko for their invaluable support provided throughout the current study. In addition, we are grateful for the assistance in the preparation of this work to the management of SE "Sumy Biological Factory".

\section{REFERENCES}

[1] O. Gavryliuk. Formation and state regulation the veterinary products market in Ukraine. Candidate's thesis. Lviv, 2018.

[2] Y. Vasutinska, and N. Kuzminska. Estimating the degree of novelty of a new product: innovative approach. Marketing and Management of Innovations, Vol. 2, pp. 282-294, 2019.

https://doi.org/10.21272/mmi.2019.2-24

[3] V. Mykhailovskyi, I. Olenych, and I. Khariv. Analysis of veterinary market segmenting criteria products relating to goods. Scientific Bulletin of LNUVMBT named after S.Z. Gzhytskyi, Vol. 1(36), pp. 297-301, 2008.

[4] N. Yeremiieva, and O. Zozuliov. E-business features in the veterinary market. Economic Bulletin of NTUU "KPI", pp. 299-306, 2017.

DOI: $10.20535 / 2307-5651.14 .2017 .108740$.

[5] I. Bushuieva I., and M. Ponomarenko (2012). Research and forecasting demand on the market of veterinary medicinal products. Ukrainian Biopharmaceutical Journal, Vol. 5-6(22-23), pp. 14-17, 2012.

[6] L. Mogylna. Management of the quality of veterinary products of Ukrainian enterprises when entering the foreign market. Economy and Society, Vol. 8, pp. 72-77, 2017.

[7] O. Gavryliuk O. Ethical aspects of veterinary marketing, 2010. URL: http://ena.lp.edu.ua:8080/bitstream /ntb/7532/1/05.pdf.

[8] G. Garvas, and P. Muzyka (2017). Clustering of production of veterinary preparations in the conditions of European integration. Scientific Messenger of Lviv National University of Veterinary Medicine and Biotechnologies, Vol. 19(81), pp. 118-122, 2017. DOI: 10.15421/nvlvet8121.

[9] O. Strus, N. Polovko, and K. Smetanina. Marketing aspects of the development of veterinary preparations based on peloids and products of their processing. Socialna 
farmaciâ v ohoronì zdorovâ, Vol. 5(2), pp. 75-84, 2019. DOI: 10.24959/sphhcj.19.154.

[10] G. Rajkumar. Marketing authorization of veterinary products in Thailand. International Journal of Drug Regulatory Affairs, Vol. 4(1), pp. 21-23, 2016.

[11] P.N. Munyole. Marketing strategies adopted by veterinary pharmaceutical firms in Kenya to enhance performance. Research project presented in partial fulfillment of the requirements for the award of the degree of Masters of business administration University of Nairobi, 2015.

[12] S. Sneeringer. Incentivizing new veterinary pharmaceutical products to combat antibiotic resistance, 2019. URL: https://academic.oup.com/aepp/advancearticle-abstract/doi/10.1093/

aepp/ppz022/5568261?redirectedFrom=fulltext.

[13] E. Isaeva. Basic internet marketing tools for industrial companies. Bulletin of Omsk University. Series "Economics", Vol. 4, pp. 85-91, 2016.

[14] H. Harvas, and V. Kolodiichuk. Features of assessment of competitiveness of veterinary preparations. Scientific Bulletin of LNUVMBT named after S.Z. Gzhytskyi, Vol. 21(93), pp. 92-95, 2019.

https://doi.org/10.32718/nvlvet-e9318

[15] L. Syhyda. Influence of enterprise's marketing environment on process of marketing distribution policy development. Economic Annals-XXI, Vol. 7, pp. 28-32, 2013. [16] Official site of CEDEM. Law of Ukraine "About advertising"

URL:

https://cedem.org.ua/library/zakon-ukrayiny-pro-reklamu.

[17] A. Teletov, N. Letunovska, and M. Provozin. Social infrastructure of modern enterprises and territories. Sumy: Trytoriia, 2019.

[18] Most used social networks in Ukraine in 2019. Statista. URL: https://www.statista.com/statistics/1057085/ most-used-social-networks-ukraine/.

[19] Jenie L. Plender et al., Adoption Factors on Online Money Transfer Services in a Developing Country: A View on Extended Unified Theory of Acceptance and Use of Technology. International Journal of Advanced Trends in Computer Science and Engineering, 9(1.1), 2020, 129 - 137

https://doi.org/10.30534/ijatcse/2020/2491.12020 